Click

Here

Full

Article

\title{
Species-specific responses of calcifying algae to changing seawater carbonate chemistry
}

\section{Gerald Langer and Markus Geisen}

Biogeosciences, Biological Oceanography, Alfred Wegener Institute for Polar and Marine Research, Am Handelshafen 12, D-27570 Bremerhaven, Germany (glanger@awi-bremerhaven.de; mgeisen@awi-bremerhaven.de)

Karl-Heinz Baumann

Geosciences, University of Bremen, Klagenfurter Str., D-28359 Bremen, Germany (baumann@uni-bremen.de)

\section{Jessica Kläs and Ulf Riebesell}

Leibniz Institute for Marine Sciences, IFM-GEOMAR, Düsternbrooker Weg 20, D-24105 Kiel, Germany (jklaes@ifm-geomar.de; uriebesell@ifm-geomar.de)

\section{Silke Thoms}

Biogeosciences, Alfred Wegener Institute for Polar and Marine Research, Am Handelshafen 12, D-27570 Bremerhaven, Germany (sthoms@awi-bremerhaven.de)

\section{Jeremy R. Young}

The Natural History Museum, Cromwell Road, London, SW7 5BD, United Kingdom (j.young@nhm.ac.uk)

[1] Uptake of half of the fossil fuel $\mathrm{CO}_{2}$ into the ocean causes gradual seawater acidification. This has been shown to slow down calcification of major calcifying groups, such as corals, foraminifera, and coccolithophores. Here we show that two of the most productive marine calcifying species, the coccolithophores Coccolithus pelagicus and Calcidiscus leptoporus, do not follow the $\mathrm{CO}_{2}$-related calcification response previously found. In batch culture experiments, particulate inorganic carbon (PIC) of C. leptoporus changes with increasing $\mathrm{CO}_{2}$ concentration in a nonlinear relationship. A PIC optimum curve is obtained, with a maximum value at present-day surface ocean $\mathrm{pCO}_{2}$ levels $\left(\sim 360 \mathrm{ppm} \mathrm{CO}_{2}\right)$. With particulate organic carbon (POC) remaining constant over the range of $\mathrm{CO}_{2}$ concentrations, the PIC/POC ratio also shows an optimum curve. In the $C$. pelagicus cultures, neither PIC nor POC changes significantly over the $\mathrm{CO}_{2}$ range tested, yielding a stable PIC/POC ratio. Since growth rate in both species did not change with $\mathrm{pCO}_{2}$, POC and PIC production show the same pattern as POC and PIC. The two investigated species respond differently to changes in the seawater carbonate chemistry, highlighting the need to consider species-specific effects when evaluating whole ecosystem responses. Changes of calcification rate (PIC production) were highly correlated to changes in coccolith morphology. Since our experimental results suggest altered coccolith morphology (at least in the case of C. leptoporus) in the geological past, coccoliths originating from sedimentary records of periods with different $\mathrm{CO}_{2}$ levels were analyzed. Analysis of sediment samples was performed on six cores obtained from locations well above the lysocline and covering a range of latitudes throughout the Atlantic Ocean. Scanning electron micrograph analysis of coccolith morphologies did not reveal any evidence for significant numbers of incomplete or malformed coccoliths of $C$. pelagicus and C. leptoporus in last glacial maximum and Holocene sediments. The discrepancy between experimental and geological results might be explained by adaptation to changing carbonate chemistry. 
Components: 6566 words, 5 figures, 2 tables, 1 dataset.

Keywords: calcification; coccolithophores; morphology; ocean acidification.

Index Terms: 0414 Biogeosciences: Biogeochemical cycles, processes, and modeling $(0412,0793,1615,4805,4912)$.

Received 19 December 2005; Revised 10 March 2006; Accepted 25 May 2006; Published 20 September 2006.

Langer, G., M. Geisen, K.-H. Baumann, J. Kläs, U. Riebesell, S. Thoms, and J. R. Young (2006), Species-specific responses of calcifying algae to changing seawater carbonate chemistry, Geochem. Geophys. Geosyst., 7, Q09006, doi:10.1029/ 2005 GC001227.

\section{Introduction}

[2] Since the mid 19th century, fossil fuel burning has released more than 250 billion tons of carbon in the form of $\mathrm{CO}_{2}$ into the atmosphere [Houghton et al., 2001]. Nearly $50 \%$ of the fossil fuel $\mathrm{CO}_{2}$ emitted into the atmosphere was subsequently taken up by the ocean, $80 \%$ of which is stored in the upper $200 \mathrm{~m}$ of the water column [Sabine et al., 2004]. While ocean uptake of anthropogenic $\mathrm{CO}_{2}$ provides an invaluable service by mitigating $\mathrm{CO}_{2}-$ related global warming, it leads to a continuous acidification of surface ocean seawater. Unabated $\mathrm{CO}_{2}$ emissions will cause a doubling in surface ocean $p \mathrm{CO}_{2}$ levels over their preindustrial values by the middle of this century, accompanied by a decrease in surface ocean $\mathrm{pH}$ three times greater than that experienced during the transition from glacial to interglacial periods [Wolf-Gladrow et al., 1999]. Ocean acidification and the related changes in seawater chemistry may directly impact marine organisms and ecosystems.

[3] Recent laboratory and field studies have revealed a profound effect of seawater acidification and the related decrease in carbonate saturation state on the calcification rates of individual species and communities in both planktic and benthic habitats (Bijma et al. [1999] (I); Delille et al. [2005] (II); Kleypas et al. [1999] (III); Riebesell et al. [2000] (II)). Foraminifera (I), coccolithophores (II), and corals (III) each showed a decrease in calcification with increasing $\mathrm{CO}_{2}$ concentration. $\mathrm{A} \mathrm{CO}_{2}$ doubling from preindustrial values of $280 \mathrm{ppm}$ $\mathrm{pCO}_{2}$ to $560 \mathrm{ppm} \mathrm{pCO}_{2}$ caused a decreased in calcium carbonate precipitation by $5-25 \%$ in all calcifying organisms investigated to date [Feely et al., 2004]. This rather uniform response appears enigmatic considering that major differences exist between the calcifying groups with regard to (1) the mineral phase of $\mathrm{CaCO}_{3}$ produced, (2) the location of $\mathrm{CaCO}_{3}$ precipitation, and (3) the pathways of the associated ion transport. Whereas the aragonitic structures of corals are formed at external surfaces providing microenvironments favoring $\mathrm{CaCO}_{3}$ precipitation, the calcitic shells and platelets of foraminifera and coccolithophores are produced internally in calcifying compartments through vacuolization of seawater [Erez, 2003] and via transmembrane ion transport [Brownlee and Taylor, 2004].

[4] Despite the apparent consistency in the observed $\mathrm{CO}_{2}$ effects on biogenic calcification, predictions about the fate of calcifying organisms in an increasingly acidified ocean are problematic. Most results presently available are based on short-term experiments with calcifying organisms dominant in the present ocean. This may have created a bias for species and clones best adapted to modern $\mathrm{CO}_{2}$ levels and raises questions regarding the general validity of the observed responses. It is also unknown whether calcifiers are capable to adapt to decreasing carbonate saturation states and at what rate. Aside from testing a wider range of calcifying species, there is obviously a need to examine long-term effects of $\mathrm{CO}_{2}$-related changes in seawater chemistry.

[5] In the present study we have combined experimental results of two previously untested coccolithophore species, Calcidiscus leptoporus and Coccolithus pelagicus, with the examination of coccolith morphology in glacial and preindustrial marine sediments as well as from laboratory assay. C. leptoporus and C. pelagicus are two of the heaviest calcifying extant coccolithophores and, alongside with the bloom forming cosmopolitan Emiliania huxleyi, the most important species in terms of calcite export to the sediment [Broerse et al., 2000]. Comparison of short-term responses of calcification to abrupt $\mathrm{CO}_{2}$ perturbations as observed in the laboratory with coccoliths originating from sedimentary records of periods with different $\mathrm{CO}_{2}$ levels provides first evidence for adaptation 
Table 1. Data Set Derived From the Experiments

\begin{tabular}{|c|c|c|c|c|c|c|c|c|c|}
\hline & \multicolumn{6}{|c|}{ C. leptoporus AC365 Experiment Number } & \multicolumn{3}{|c|}{$\begin{array}{l}\text { C. pelagicus AC400 } \\
\text { Experiment Number }\end{array}$} \\
\hline & 1 & 2 & 3 & 4 & 5 & 6 & 7 & 8 & 9 \\
\hline \multicolumn{10}{|c|}{ Medium Chemistry } \\
\hline $\mathrm{pCO}_{2}, \mu \mathrm{atm}$ & 98 & 216 & 345 & 477 & 768 & 920 & 149 & 345 & 915 \\
\hline $\mathrm{CO}_{2}, \mu \mathrm{mol} \mathrm{kg}{ }^{-1}$ & 3.2 & 7.1 & 11.3 & 15.7 & 25.3 & 30.3 & 5.4 & 12.4 & 32.8 \\
\hline $\mathrm{HCO}_{3}^{-}, \mu \mathrm{mol} \mathrm{kg}{ }^{-1}$ & 1614 & 1807 & 1901 & 1941 & 1987 & 1973 & 1692 & 1813 & 1871 \\
\hline $\mathrm{CO}_{3}{ }^{2-}, \mu \mathrm{mol} \mathrm{kg}{ }^{-1}$ & 516 & 306 & 203 & 160 & 104 & 82 & 340 & 169 & 68 \\
\hline DIC, $\mu \mathrm{mol} \mathrm{kg}$ & 2133 & 2121 & 2115 & 2116 & 2116 & 2086 & 2038 & 1994 & 1971 \\
\hline $\mathrm{TA}, \mu \mathrm{mol} \mathrm{kg}{ }^{-1}$ & 2827 & 2548 & 2393 & 2336 & 2248 & 2179 & 2517 & 2234 & 2047 \\
\hline $\mathrm{pH}, \mathrm{NBS}$ & 8.74 & 8.44 & 8.27 & 8.13 & 7.93 & 7.86 & 8.56 & 8.22 & 7.81 \\
\hline omega & 12.8 & 7.5 & 5.0 & 3.9 & 2.6 & 2.0 & 8.3 & 4.1 & 1.7 \\
\hline \multicolumn{10}{|c|}{ Sample Parameters } \\
\hline pg POC cell ${ }^{-1}$ & 74 & 63 & 66 & 63 & 69 & 67 & 184 & 198 & 218 \\
\hline pg PIC cell ${ }^{-1}$ & 93 & 122 & 146 & 130 & 118 & 101 & 276 & 338 & 354 \\
\hline PIC/POC & 1.25 & 1.94 & 2.22 & 2.05 & 1.71 & 1.55 & 1.50 & 1.70 & 1.63 \\
\hline P $(\mu)$ POC, pg POC cell ${ }^{-1}$ day $^{-1}$ & 36 & 41 & 42 & 39 & 44 & 40 & 143 & 144 & 158 \\
\hline P $(\mu)$ PIC, pg PIC cell ${ }^{-1}$ day $^{-1}$ & 45 & 78 & 94 & 80 & 75 & 62 & 214 & 245 & 256 \\
\hline Growth rate $\mu$ (per day) & 0.48 & 0.64 & 0.64 & 0.62 & 0.63 & 0.62 & 0.78 & 0.73 & 0.73 \\
\hline \multicolumn{10}{|c|}{ Coccolith Morphology } \\
\hline Sphere size, $\mu \mathrm{m}$ & 12.6 & & 14.7 & & & 13.2 & & & \\
\hline Coccoliths/cell & 15 & 14 & 14 & 14 & 14 & 16 & & & \\
\hline (1) Normal coccoliths, \% & 11 & 45 & 52 & 47 & 19 & 4 & 50 & 54 & 53 \\
\hline (2) Malformed coccoliths, \% & 2 & 3 & 25 & 11 & 6 & 8 & 5 & 9 & 18 \\
\hline (3) Incompletely grown coccoliths, \% & 41 & 33 & 6 & 9 & 5 & 2 & 22 & 12 & 14 \\
\hline (4) Malformed and incompletely grown coccoliths, \% & 46 & 18 & 17 & 32 & 69 & 86 & 23 & 25 & 16 \\
\hline
\end{tabular}

of coccolithophore calcification to changing $\mathrm{CO}_{2}$ concentration.

\section{Material and Methods}

\subsection{Experimental Design}

[6] Monospecific cultures of Calcidiscus leptoporus (strain AC365, from South Atlantic off South Africa, CODENET culture collection, ALGOBANK http://www.nhm.ac.uk/hosted sites/ina/ CODENET/caencultures.htm) and Coccolithus pelagicus (strain AC400, from South Atlantic off Namibia, CODENET culture collection, ALGOBANK) were grown in sterile filtered $(0.2 \mu \mathrm{m})$ seawater enriched with $100 \mu \mathrm{M}$ nitrate and $6.25 \mu \mathrm{M}$ phosphate and with trace metals and vitamins according to f/2 [Guillard and Ryther, 1962]. The incident photon flux density was $350 \mu \mathrm{mol} / \mathrm{m}^{2} *_{\mathrm{s}}$ and a 16/8 hours light/dark cycle was applied. Experiments were carried out at optimum growth temperature, i.e., $20^{\circ} \mathrm{C}$ for C. leptoporus and $17^{\circ} \mathrm{C}$ for $C$. pelagicus. Cells were acclimated to experimental conditions for approximately 10 generations and grown in dilute batch cultures in triplicate [Zondervan et al., 2002]. For a summary of all measured parameters see Table 1. Low cell density at harvest (in general less than 6000 cells per $\mathrm{ml}$ ) resulted in less than $8 \%$ DIC (dissolved inorganic carbon) consumption (i.e., DIC consumed by the cells at the end of experiment) and a shift in $\mathrm{pH}$ of no more than 0.06 units. $\mathrm{CO}_{2}$ levels were adjusted by adding calculated amounts of $1 \mathrm{M}$ $\mathrm{HCl}$ or $1 \mathrm{M} \mathrm{NaOH}$ to the medium. The carbonate system of seawater can be manipulated in various ways. In an open system changes in atmospheric $\mathrm{pCO}_{2}$ cause changes in $\left[\mathrm{CO}_{2}\right], \mathrm{pH}$ and DIC, while TA (total alkalinity) remains constant. In an experiment this method requires bubbling with $\mathrm{CO}_{2}$ gas. The addition of $\mathrm{HCl}$ or $\mathrm{NaOH}$ to a closed system affects $\left[\mathrm{CO}_{2}\right], \mathrm{pH}$, and TA, while DIC remains constant. Precise manipulations of the carbonate system are easier to achieve applying the latter method, which is the reason why it was applied in this study. Changes in DIC or TA with respect to the $\mathrm{CO}_{2}$ range tested are on the order of $10 \%$ and therewith not likely to produce an effect on the measured parameters. Experiments in which DIC was altered should thus be comparable to experiments in which TA was altered. In order to prevent gas exchange with the atmosphere 2.41 borosilicate flasks were filled without headspace and closed with Teflon lined screw caps. Determination of 
growth rate, however, required regular sampling for cell counts, thereby creating a maximum headspace of $6 \mathrm{ml}$. The resultant air-water $\mathrm{CO}_{2}$ equilibration of $3 \%$ shift in $\mathrm{CO}_{2}$ aq concentration is negligible. Samples for alkalinity measurements were filtered (approx. $0.6 \mu \mathrm{m}$ ), poisoned with $1 \mathrm{~mL}$ of a $\mathrm{HgCl}_{2}$ solution $(35 \mathrm{~g} / \mathrm{l})$ and stored in $300 \mathrm{~mL}$ borosilicate flasks at $0^{\circ} \mathrm{C}$. DIC samples were sterile filtered $(0.2 \mu \mathrm{m})$ and stored in $13 \mathrm{~mL}$ borosilicate flasks free of air bubbles at $0^{\circ} \mathrm{C}$. Total alkalinity was calculated from linear Gran plots [Gran, 1952] after duplicate potentiometric titration [Bradshaw et al., 1981; Brewer et al., 1986] and DIC was measured photometrically [Stoll et al., 2001] in triplicate. Precision of the total alkalinity measurements is $\sim 3 \mu \mathrm{mol} / \mathrm{L}$ and accuracy $\sim 4 \mu \mathrm{mol} / \mathrm{L}$. For dissolved inorganic carbon precision is $\sim 4 \mu \mathrm{mol} / \mathrm{L}$ and accuracy $\sim 5 \mu \mathrm{mol} / \mathrm{L}$. The carbonate system was calculated from temperature, salinity, and the concentrations of DIC, total alkalinity and phosphate, using the program $\mathrm{CO}_{2}$ sys [Lewis and Wallace, 1998]. Equilibrium constants of Mehrbach et al. [1973] refit by Dickson and Millero [1987] were chosen. Samples for determination of total particulate carbon and particulate organic carbon were filtered on precombusted (12 hours, $500^{\circ} \mathrm{C}$ ) GF/F-filters (approx. $0.6 \mu \mathrm{m}$ ) and stored at $-20^{\circ} \mathrm{C}$. Prior to analysis, the POC filters were fumed for two hours with a saturated $\mathrm{HCl}$ solution to remove all inorganic carbon. TPC and POC were subsequently measured on a Carlo Erba NA-1500 Analyzer. Particulate inorganic carbon (PIC) was calculated as the difference between TPC and POC. For determination of cell density samples were taken daily or every other day, stored at $0^{\circ} \mathrm{C}$ and counted within 3 hours after sampling using a Sedgwick Rafter counting cell. Cell density was plotted against time and growth rate $(\mu)$ was calculated by means of exponential regression. Inorganic and organic carbon production $(\mathrm{P}, \mathrm{pg}$ $\mathrm{C} /$ cell*d) was calculated according to $P=\mu^{*}$ (cellular carbon content).

\subsection{Coccolith Morphology}

[7] Samples for scanning electron microscope analysis were filtered on cellulose nitrate filters $(0.45 \mu \mathrm{m}$ pore size), dried in a drying cabinet at $60^{\circ} \mathrm{C}$ for 24 hours, then sputter-coated with goldpalladium. Imaging was performed with a Philips XL-30 digital scanning field-emission electron microscope. Four categories were used to describe the morphology of C. leptoporus: normal, malformed, incomplete, and incomplete and malformed coccoliths (for reference images for the categories, see Figure S3 in the auxiliary material ${ }^{1}$ ). An average of approx. 500 coccoliths was analyzed per $\mathrm{CO}_{2}$ treatment. The relative numbers of coccoliths in the four categories were constant when counting more than 50 coccoliths, so that the relative numbers obtained from counting 500 coccoliths can safely be regarded as statistically significant. In order to get a morphological index of reduced cellular calcite content we combined the two categories containing incompletely grown coccoliths, since an incompletely grown coccolith contains less calcite than a completely grown one (including the malformed coccoliths). The relative number of all incompletely grown coccoliths is given in Table 1 .

\subsection{Sediment Core Samples}

[8] Six cores were selected for the geological control study representing a range of latitudes through the Atlantic Ocean; all cores were from well above the lysocline. The LGM sample set used here is mostly adopted from the GLAMAP2000 study [Niebler et al., 2003; Pflaumann et al., 2003], which greatly benefits from a detailed $\mathrm{AMS}^{14} \mathrm{C}$-stratigraphy or other high-resolution age control and careful selection of the LGM interval. In addition, we tried to investigate the topmost centimeter of the sediment to generate a modern reference data set. Although most of the samples were taken with a multicorer or a giant box corer, we cannot exclude that due to bioturbation and sampling disturbances the surface sediment samples represent up to 1,500 years in open ocean areas [Andruleit and Baumann, 1998]. As a consequence sedimentation predominantly took place under preindustrial $\mathrm{CO}_{2}$ levels of roughly $280 \mathrm{ppmv}$ [Indermühle et al., 1999]. From each core one sample was taken from the last glacial maximum (LGM) when $\mathrm{CO}_{2}$ levels are believed to have been $\sim 180$ ppmv [Petit et al., 1999], and a second from the sediment top (i.e., upper $1 \mathrm{~cm}$ of the core).

[9] For the counting of core top and LGM core samples the same procedure of dividing the coccoliths into categories and determining the relative numbers of coccoliths in the respective categories was applied. This allowed a quantitative comparison of coccolith morphology.

\section{Results}

[10] The laboratory assay consisted of batch culture incubations of C. leptoporus and C. pelagicus

\footnotetext{
${ }^{1}$ Auxiliary material is available at ftp://ftp.agu.org/apend/gc/ $2005 \mathrm{gc} 001227$.
} 


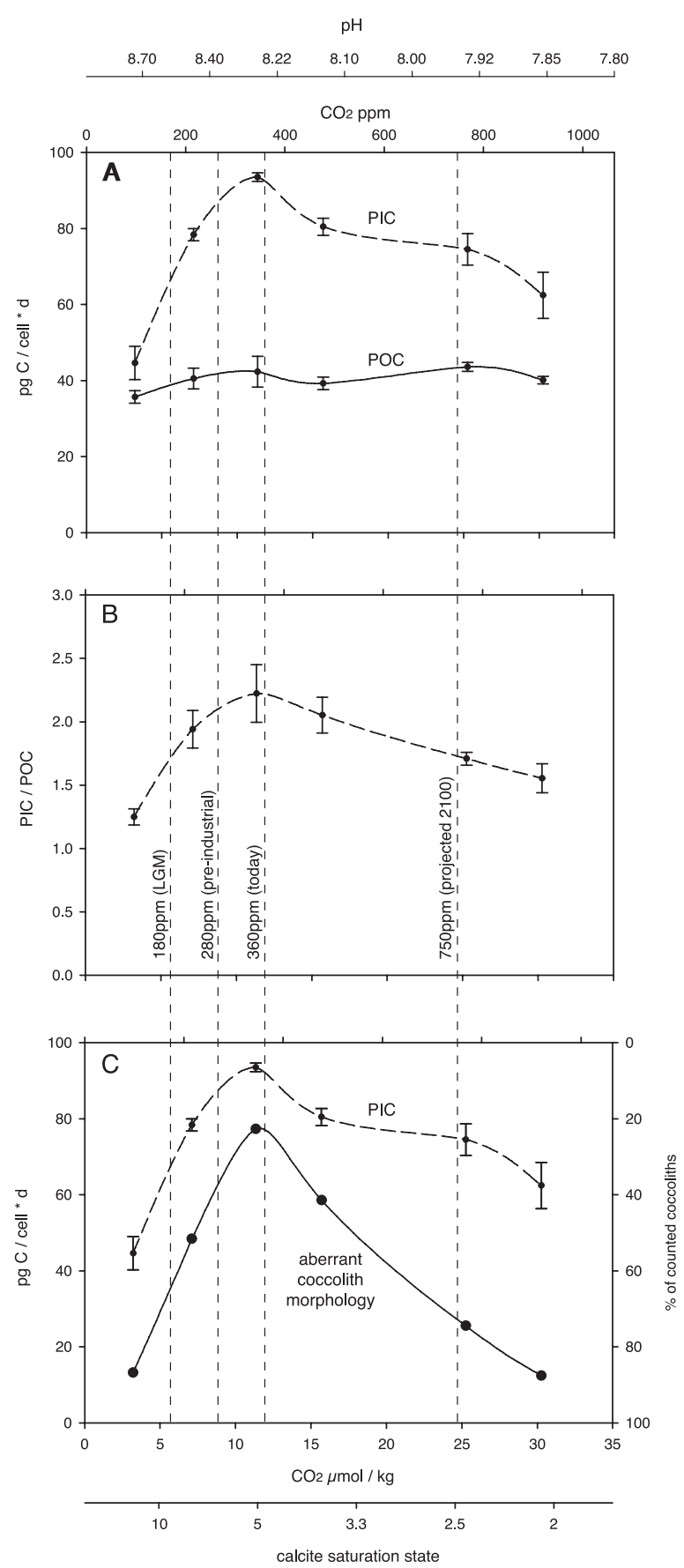

Figure 1. Data from C. leptoporus culture experiments plotted against carbonate chemistry in the culture medium ( $\mathrm{pH}$ scale is NBS). (a) Production of inorganic (dashed line) and organic (solid line) carbon per cell and day. (b) Ratio of inorganic to organic carbon content. (c) Production of inorganic carbon per cell and day (as in Figure 1a, dashed line) and relative number of incompletely grown and incompletely grown/malformed coccoliths (solid line). grown over a range of $\mathrm{CO}_{2}$ concentrations (Table 1) in which cellular particulate inorganic carbon (PIC), particulate organic carbon (POC), growth rate, and coccolith morphology were monitored. In C. leptoporus the cellular inorganic carbon content changes with increasing $\mathrm{CO}_{2}$ concentration in a nonlinear relationship (Figure 1). An optimum curve is obtained, with a maximum value at modern surface ocean $\mathrm{pCO}_{2}$ levels $(\sim 360 \mathrm{ppm}$ $\mathrm{CO}_{2}$ ). With the cellular organic carbon content remaining constant over the range of $\mathrm{CO}_{2}$ concentrations, the PIC/POC ratio also shows an optimum curve. Since the growth rate does not change with $\mathrm{pCO}_{2}$, rates of POC and PIC production show the same pattern as POC and PIC content per cell (Table 1). Scanning electron microscopy analysis reveals highly variable degrees of coccolith malformation and proportions of incomplete coccoliths between $\mathrm{CO}_{2}$ treatments (Figure 3). At $360 \mathrm{ppm}$ $\mathrm{CO}_{2}$ most coccoliths show normal morphology, at higher and lower $\mathrm{CO}_{2}$ concentrations the proportion of coccoliths showing incomplete growth and malformation increases notably.

[11] In C. leptoporus changes of calcification rate are highly correlated to changes in coccolith morphology. This raises the question whether decreasing calcite content per cell is due to a lowering of the calcite content per coccolith or to a reduction in the number of coccoliths per cell. Incomplete growth implies less calcite per coccolith. Plotting the relative number of incomplete coccoliths against $\mathrm{CO}_{2}$ concentration yields an optimum curve of similar shape to the inorganic carbon content per cell curve. Therefore it is likely that the changing inorganic carbon content per cell is due to altered calcite content per coccolith. This interpretation is supported by the fact that no differences in the number of visible coccoliths per cell could be observed (Table 1).

[12] In the Coccolithus pelagicus cultures neither PIC nor POC content per cell changes significantly over the $\mathrm{CO}_{2}$ range tested (Figure 2, Table 1), yielding a stable PIC/POC ratio. The significance was determined using the Student's $t$ test at a confidence level of 0.05 . Because growth rate does not change, PIC and POC production also remain constant with $\mathrm{CO}_{2}$. Scanning electron microscope analysis of $C$. pelagicus coccoliths showed no significant change in the proportions of malformed or incomplete coccoliths over the range of $\mathrm{CO}_{2}$ concentrations (Figure 2 and Figure 3).

[13] Analysis of sediment samples was performed on six cores obtained from location well above the 


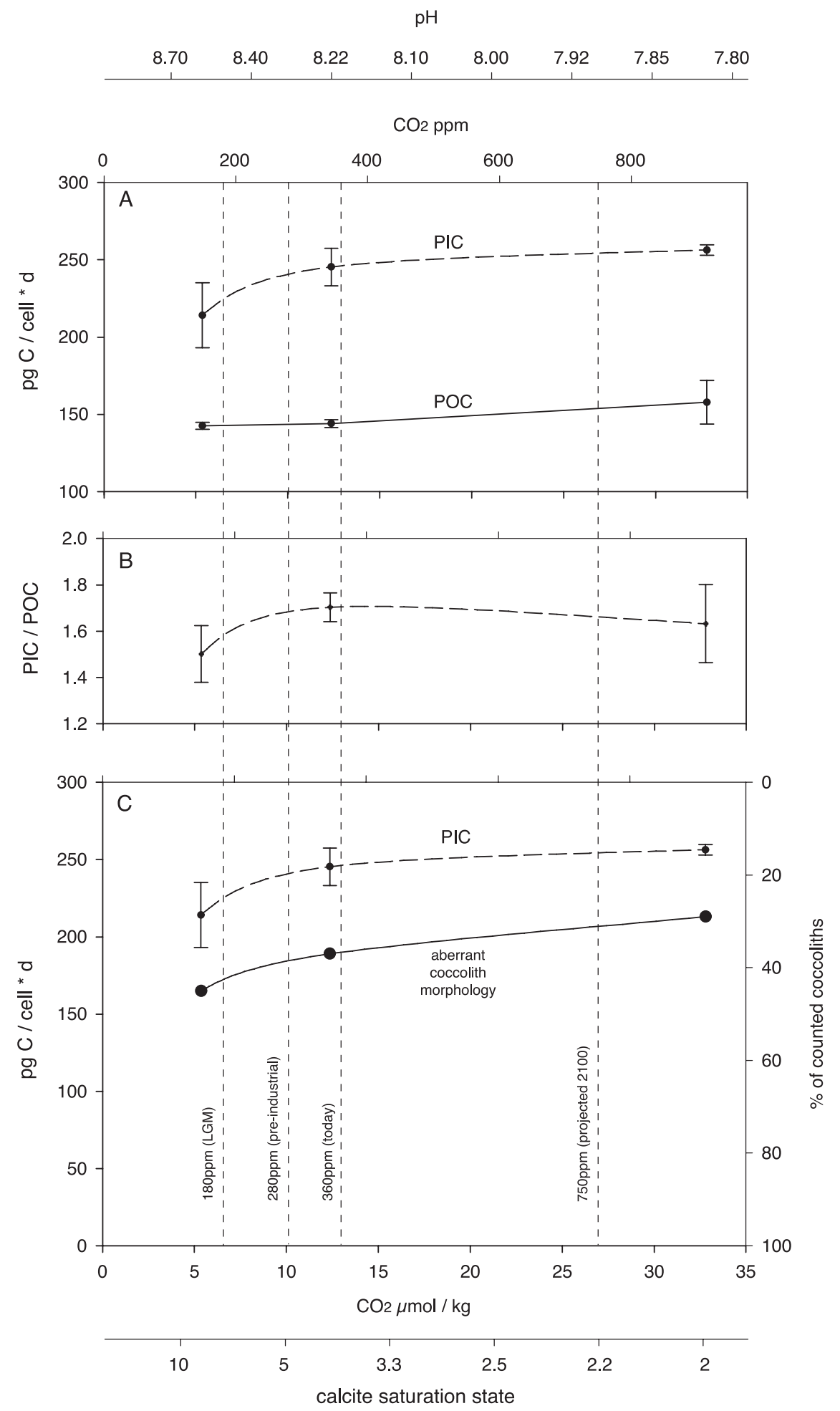

Figure 2. Data from C. pelagicus laboratory culture experiments plotted against carbonate chemistry in the culture medium. (a) Production of inorganic (dashed line) and organic (solid line) carbon per cell and day. (b) Inorganic to organic carbon ratio. (c) Production of inorganic carbon per cell and day (as in Figure 2a, dashed line) and relative number of incompletely grown and incompletely grown/malformed coccoliths (solid line). 


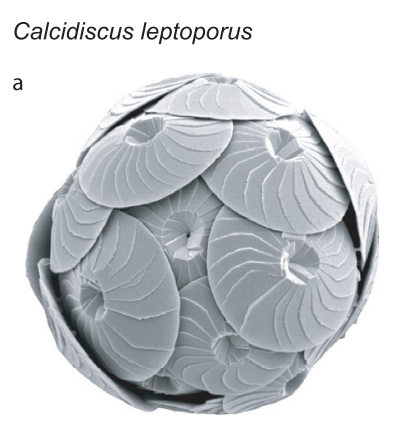

Coccolithus pelagicus

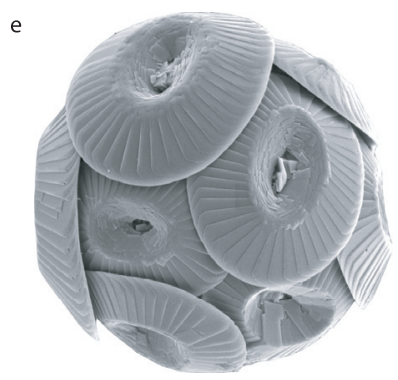

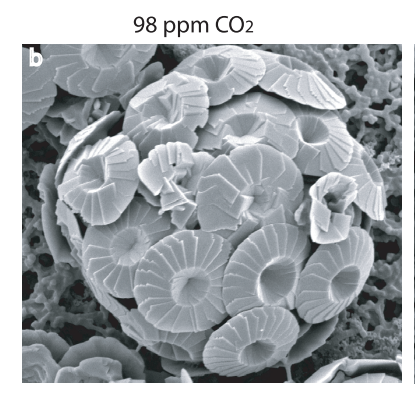

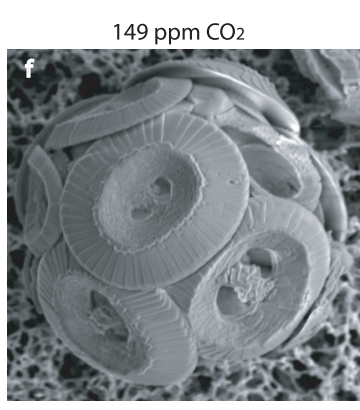

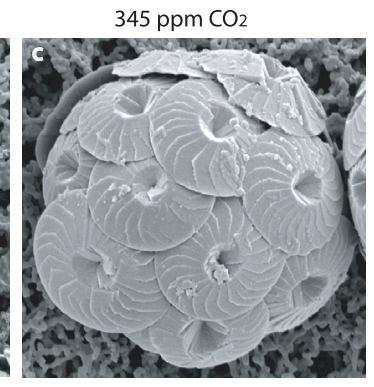

345 ppm CO 2

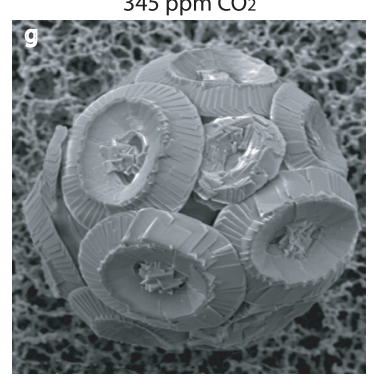

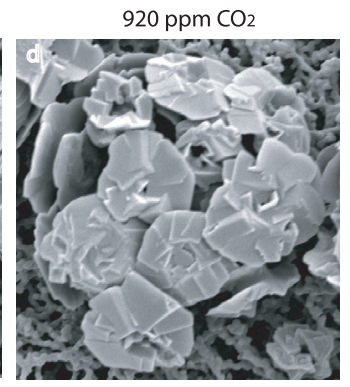

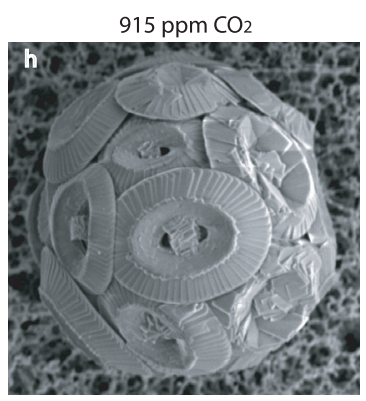

Figure 3. Representative specimens of $(\mathrm{a}-\mathrm{d})$ C. leptoporus and $(\mathrm{e}-\mathrm{h})$ C. pelagicus from (a and e) natural samples and $\left(b-d\right.$ and $\mathrm{f}-\mathrm{h}$ ) laboratory culture experiments grown at different $\mathrm{CO}_{2}$ concentrations. Note the increase in malformation and/or incomplete growth (narrow rims) with elevated or reduced $\mathrm{pCO}_{2}$ in C. leptoporus, where incomplete growth dominates samples from lower than present-day $\mathrm{pCO}_{2}$ values, whereas malformation and incomplete growth dominated the sample with higher $\mathrm{pCO}_{2}$ values.

lysocline and covering a range of latitudes throughout the Atlantic Ocean (for details, see auxiliary material). From each core one sample was taken from the last glacial maximum (LGM) when $\mathrm{CO}_{2}$ levels are believed to have been $\sim 180 \mathrm{ppmv}$ [Petit et al., 1999], and a second from the sediment top (i.e., upper $1 \mathrm{~cm}$ of the core), representing preindustrial times. Scanning electron micrograph analysis of coccolith morphologies did not reveal any evidence for significant numbers of incomplete or malformed coccoliths of C. pelagicus and C. leptoporus in LGM and Holocene sediments (Table 2). In general, carbonate overgrowth or early diagenetic alterations cannot be found in any of the samples, examples are given in Figure 4.

\section{Discussion}

[14] The assessment of the $\mathrm{CO}_{2}$ sensitivity of marine biogenic calcification is primarily based on short-term experimental studies using single clones of selected species. The observed deterioration of coccolith production above as well as below present-day $\mathrm{CO}_{2}$ concentrations in $C$. leptoporus and the lack of a $\mathrm{CO}_{2}$ sensitivity of calcification in C. pelagicus refute the notion of a linear relationship of calcification with the carbonate ion concentration and carbonate saturation state, as previously suggested for corals [e.g., Feely et al., 2004]. Consequently, species-specific effects have to be taken into account when assessing whole ecosystem responses to changing carbonate chemistry.

[15] In case of C. leptoporus, changes in coccolith morphology as occurring in response to the abrupt $\mathrm{CO}_{2}$ perturbation applied in the experimental treatments are not mirrored in the sedimentary record. This suggests that in the natural environment C. leptoporus has adjusted to the $80 \mathrm{ppm} \mathrm{CO}_{2}$ and $180 \mathrm{ppm} \mathrm{CO}_{2}$ difference between present, preindustrial and glacial times, respectively.

[16] An alternative explanation for observing only normal coccoliths in the fossil record would be selective removal through dissolution of incomplete or malformed coccoliths. This is not inconceivable, considering water column dissolution of coccoliths and assuming that malformed morphotypes may be more vulnerable to dissolution. Since dissolution is a continuous process [Hay, 2004], however, complete removal of incomplete and malformed coccoliths cannot occur without inflicting visible changes to normal coccoliths. Such changes were not observed. This reasoning was confirmed in a thorough field study in the Indonesian Seas, where the coccolith morphology of a 
LANGR GT AL: $\mathrm{kESON}$

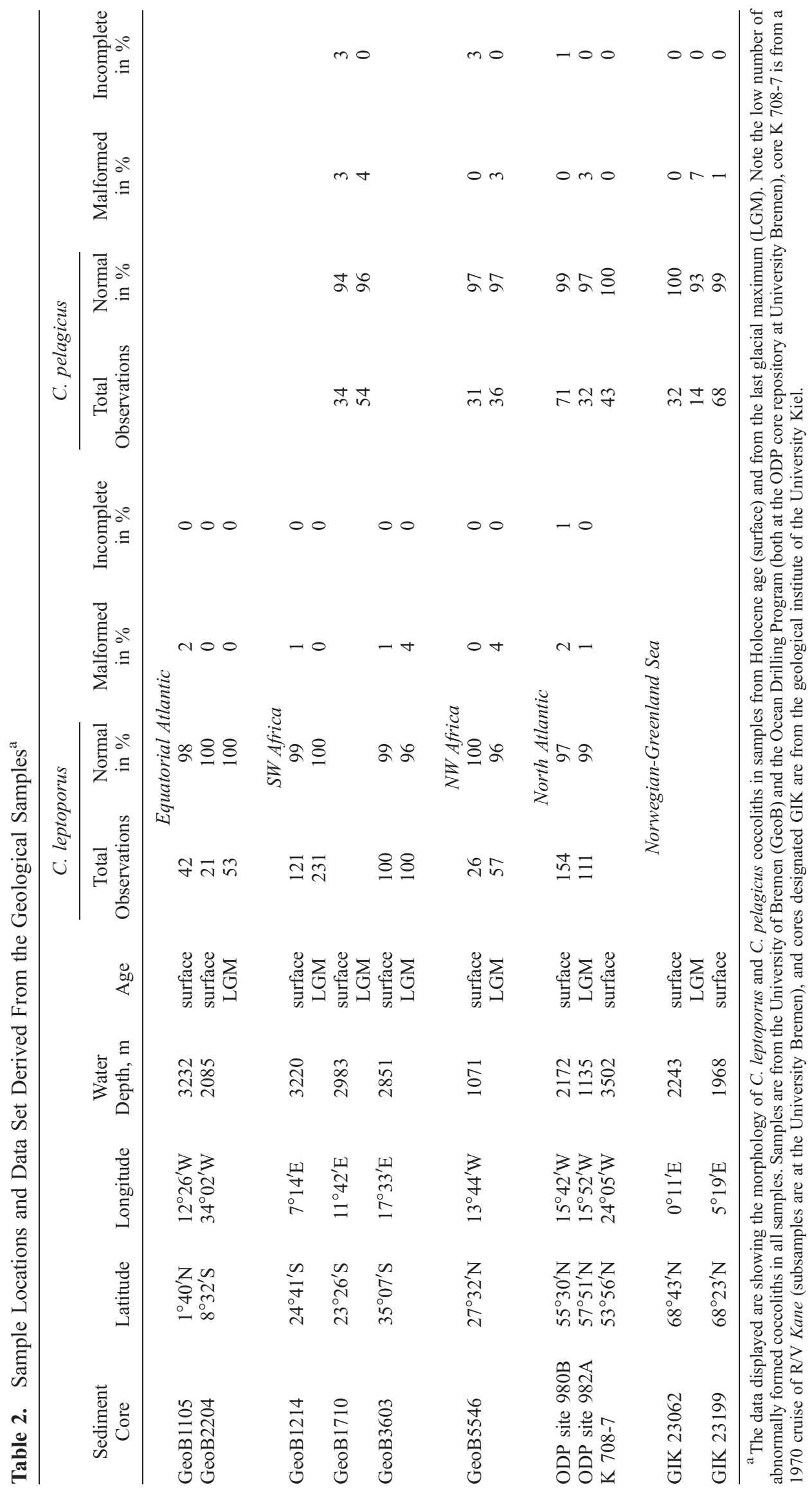




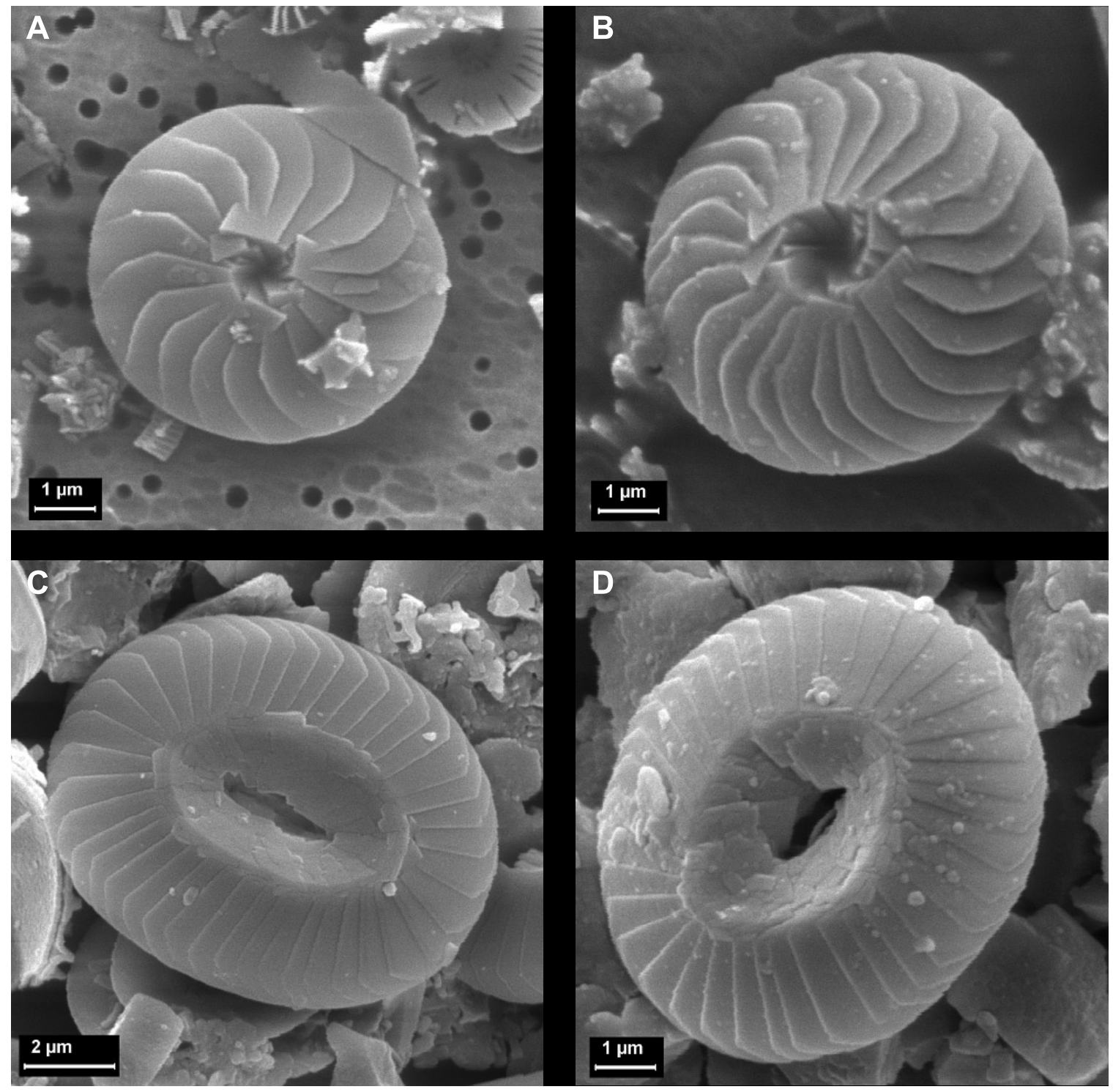

Figure 4. Representative images of coccolith morphology of the two species investigated taken from sediment samples. C. leptoporus (a) from surface sediment and (b) from the last glacial maximum. C. pelagicus (c) from surface sediment and (d) from the last glacial maximum. Images in Figures $4 \mathrm{a}$ and $4 \mathrm{~b}$ were taken from samples from core GeoB 1214; images in Figures 4c and 4d were taken from samples taken from core GK 23062; refer to Table 2.

number of different species was investigated in both surface water- and sediment trap samples [Kleijne, 1990]. This study conclusively demonstrated that in sediment trap samples both malformed and normal coccoliths were subject to dissolution and hence should be observable in the fossil record. These findings support our hypothesis that selective dissolution cannot explain our results from fossil material.

[17] Thus it is reasonable to assume that C. leptoporus has adapted its calcification mechanism to the change in carbonate chemistry having occurred since the last glacial maximum. A possible explanation for such adaptation is that the population is genetically diverse, containing strains with diverse physiological and genetic traits, as already demonstrated for E. huxleyi [Brand, 1981, 1982, 1984; Conte et al., 1998; Medlin et al., 1996; Paasche, 2002; Stolte et al., 2000]. Our experimental data for $C$. leptoporus merely reflect the physiological response of one particular strain to short term changes of $\mathrm{pCO}_{2}$. If genetic diversity is the basis of adaptation to changing $\mathrm{CO}_{2}$ concentrations, this is not likely to be confined to C. leptoporus but can be assumed to play a role in other coccolithophore 


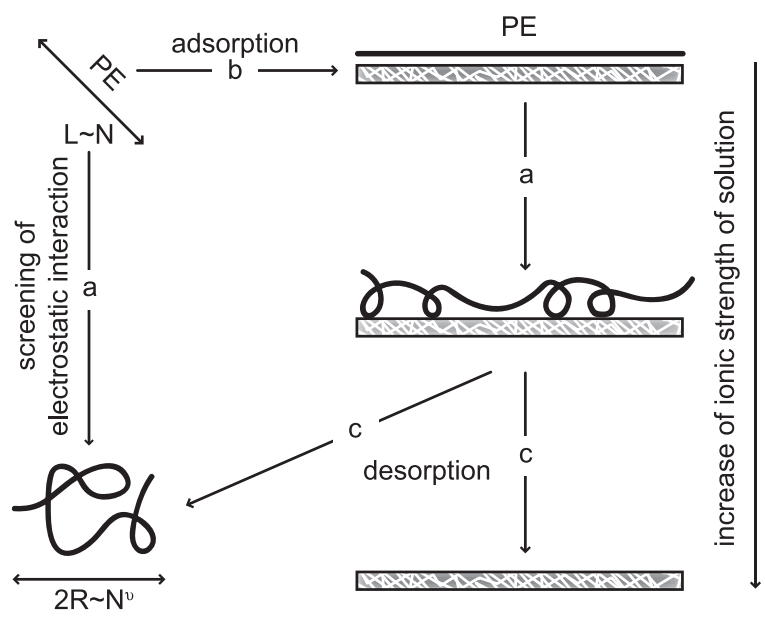

Figure 5. Behavior of polyelectrolytes (PEs) in relation to ionic strength of the solution. PEs are polymers that have ionizable groups (such as $\mathrm{SO}_{3}^{-}$or $\mathrm{CO}_{2}^{-}$). When dissolved in solutions, they dissociate into charged polymer chains (macroions) and free, mobile counterions. The delicate balance between chain configurational entropy and long range electrostatic monomer-monomer repulsion determines the structure of charged chains in dependence on the ionic strength of the solution. In the limit of low ionic strength, PEs are usually stretched and assume a rod-like conformation ( $\mathrm{L} \sim \mathrm{N}, \mathrm{N}$ is the degree of polymerization). Increasing the ionic strength (a) can significantly reduce the rigidity of the chain, since the electrostatic interaction is screened over the Debye-Hückel screening length (which typically varies from less than $1 \mathrm{~nm}$ to more than $100 \mathrm{~nm}$ ). At very high ionic strength, the distant parts of a charged chain do not interact, and the chain behaves as a random coil with short-ranged repulsive interactions $\left(\mathrm{R} \sim \mathrm{N}^{\nu}, 0.5<v<1\right)$. PEs can adsorb onto a charged surface (b) mainly caused by electrostatic effects. At low ionic strength, adsorption is very strong, and the PEs assume a conformation where the chain essentially lies flat on the surface. As the ionic strength is increased (a), the polymer chain can gain conformational entropy by extending somewhat into the solution. In the limit of high ionic strength, PEs can desorb from the surface (c).

species as well. The sexual life cycle of coccolithophores ensures extensive genetic recombination, resulting in natural populations with significant ecophysiological variability [Geisen et al., 2004; Paasche, 2002].

[18] On the cellular level the influence of changing carbonate chemistry can be interpreted in terms of a $\mathrm{pH}$ effect. It is well known that in many species changes in extracellular $\mathrm{pH}$ exert an influence on various physiological parameters, e.g., intracellular pH [Nimer et al., 1994], nitrate uptake [Thoresen et al., 1984] and membrane potential [Felle, 1994]. A constant membrane potential is the result of a sophisticated ion balance mechanism. Hence it is likely that sudden external $\mathrm{pH}$ changes can upset this ion balance and consequently alter ionic composition and ionic strength of the cell. Intracellular ionic strength in turn determines the conformation of polyelectrolytes, e.g., cytoskeletal elements and coccolith-associated polysaccharides. According to polymer theory [Odijk, 1977; Skolnick and Fixman, 1977] changes in ionic strength can turn a rod-like polyelectrolyte into a coil (Figure 5), thereby disturbing its specific function. Both the cytoskeleton and the coccolith associated polysaccharides are thought to play an important role in coccolith morphogenesis [Henriksen et al., 2004; Marsh, 1994]. Conformational changes of these polyelectrolytes may have caused the observed coccolith malformation. On longer timescales however, the population may be able to evolve so that the optimal $\mathrm{CO}_{2}$ level for calcification of the species tracks the environmental value.

[19] This study provides the first examination of possible effects of changing $\mathrm{pCO}_{2}$ on coccolithophore calcification that does not entirely rely on experimental, i.e., very short, timescales. For planktic foraminifera there are both experimental [Bijma et al., 1999] and geological [Barker and Elderfield, 2002] observations suggesting a decline of calcification rates in response to carbonate ion concentration of seawater. Because these two studies use different species, a combination of the two approaches, as presented in this study, is not possible. Nonetheless, the foraminiferal data support the notion of a decrease in calcification on geological timescales whereas our coccolithophore data do not. It is generally accepted that in coccolithophores there is no obvious correlation between coccolith morphology, in terms of size and degree of calcification, and $\mathrm{CO}_{2}$ levels (calcium carbonate saturation state) on geological timescales. The Pleistocene, for example, an epoch of low $\mathrm{pCO}_{2}$ levels and slightly higher values of calcite saturation state compared to the Eocene and the Late Cretaceous [Demicco et al., 2003; Pearson and Palmer, 2000; Retallack, 2001; van Andel et al., 1977] is characterized by small lightly calcified coccoliths. In contrast, the Eocene and the late Cretaceous are times of large and heavily calcified coccoliths [Perch-Nielsen, 1985]. Further research is clearly warranted to elucidate the possible differences between the various groups of marine calcifiers with respect to the $\mathrm{CO}_{2}$ sensitivity of their calcification processes. 
[20] Our experimental data suggest a marked alteration in coccolith morphology of $C$. leptoporus with high levels of malformed and incomplete coccoliths when $\mathrm{CO}_{2}$ levels are reduced to last glacial maximum values. A survey of $C$. leptoporus coccoliths from the last glacial maximum (LGM) at various sites in the Atlantic Ocean did not reveal altered morphology of $C$. leptoporus coccoliths. Since the LGM, $\mathrm{CO}_{2}$ levels have risen from 180 to $370 \mathrm{ppm}$. The time interval of $\sim 18000$ years arguably provides ample time for adaptation via evolutionary processes. Malformed or incompletely grown specimens were also not observed in natural assemblages (screened prior to the industrial revolution and in the course of the last 150 years) as well as in Holocene samples (for details, see auxiliary material). Since the industrial revolution the rate of $\mathrm{CO}_{2}$ increase was 10 and possibly 100 times faster than at any other time in the past 420,000 years [Falkowski et al., 2000]. The absence of a detectable alteration in coccolith morphology in natural samples suggests that adaptation to changing $\mathrm{CO}_{2}$ levels occurred on much shorter timescale (i.e., hundreds of years). Whether adaptation to the projected future increase in $\mathrm{CO}_{2}$ related ocean acidification will be possible, is presently unknown. The lack of $\mathrm{CO}_{2}$ sensitivity observed in $C$. pelagicus, however, suggests that the dependence of calcification on carbonate saturation state is less uniform than previously thought. Genetic diversity, both between and within species, may allow calcifying organisms to prevail in a high $\mathrm{CO}_{2}$ ocean as long as seawater remains supersaturated with respect to calcite and aragonite.

\section{Acknowledgments}

[21] The first two authors contributed equally to the manuscript. The authors would like to thank Ian Probert (Algobank, Universite de Caen, France), who has provided cultures of the species investigated, Anja Terbrüggen and Christiane Lorenzen (AWI Bremerhaven) for laboratory assistance. Ulrich Bathmann, Victoria Fabry, Jan van Hinte, Toby Tyrell, and Dieter Wolf-Gladrow have made valuable comments on previous versions of this manuscript. The constructive criticism of two anonymous reviewers has helped to increase the quality of this manuscript.

\section{References}

Andruleit, H., and K.-H. Baumann (1998), History of the Last Deglaciation and Holocene in the Nordic seas as revealed by coccolithophore assemblages, Mar. Micropaleontol., 35, 179-201.

Barker, S., and H. Elderfield (2002), Foraminiferal calcification response to glacial-interglacial changes in atmospheric $\mathrm{CO}_{2}$, Science, 297, 833-836.
Bijma, J., H. J. Spero, and D. W. Lea (1999), Reassessing foraminiferal stable isotope geochemistry: Impact of the oceanic carbonate system (Experimental results), in Use of Proxies in Paleoceanography: Examples From the South Atlantic, pp. 489-521, edited by G. Fischer and G. Wefer, Springer, New York.

Bradshaw, A. L., P. G. Brewer, D. K. Shaffer, and R. T. Williams (1981), Measurements of total carbon dioxide and alkalinity by potentiometrc titration in the GEOSECS program, Earth Planet. Sci. Lett., 55, 99-115.

Brand, L. E. (1981), Genetic variability in reproduction rates in marine phytoplankton populations, Evolution, 38, 11171127.

Brand, L. E. (1982), Genetic variability and spatial patterns of genetic differentiation in the reproductive rates of the marine coccolithophores Emiliania huxleyi and Gephyrocapsa oceanica, Limnol. Oceanogr., 27, 236-245.

Brand, L. E. (1984), The salinity tolerance of forty-six marine phytoplankton isolates, Estuarine Coastal Shelf Sci., 18, 543-556.

Brewer, P. G., A. L. Bradshaw, and R. T. Williams (1986), Measurement of total carbon dioxide and alkalinity in the north Atlantic Ocean in 1981, in The Changing Carbon Cycle-A Global Analysis, edited by J. R. Trabalka and D. E. Reichle, pp. 358-381, Springer, New York.

Broerse, A. T. C., P. Ziveri, and S. Honjo (2000), Coccolithophore $\left(-\mathrm{CaCO}_{3}\right)$ flux in the Sea of Okhotsk: Seasonality, settling and alteration processes, Mar. Micropaleontol., 39, $179-200$.

Brownlee, C., and A. Taylor (2004), Calcification in coccolithophores: A cellular perspective, in Coccolithophores From Molecular Processes to Global Impact, edited by H. R. Thierstein and J. R. Young, pp. 31-49, Springer, New York.

Conte, M., A. Thompson, D. Lesley, and R. P. Harris (1998), Genetic and physiological influences on the alkenone/alkenonate versus growth temperature relationship in Emiliania huxleyi and Gephyrocapsa oceanica, Geochim. Cosmochim. Acta, 62, 51-68.

Delille, B., et al. (2005), Response of primary production and calcification to changes of $p \mathrm{CO}_{2}$ during experimental blooms of the coccolithophorid Emiliania huxleyi, Global Biogeochem. Cycles, 19, GB2023, doi:10.1029/2004GB002318.

Demicco, R. V., T. K. Lowenstein, and L. A. Hardie (2003), Atmospheric $\mathrm{pCO}_{2}$ since $60 \mathrm{Ma}$ from records of seawater $\mathrm{pH}$, calcium, and primary carbonate mineralogy, Geology, 31, 793-796.

Dickson, A. G., and F. J. Millero (1987), A comparison of the equilibrium constants for the dissociation of carbonic acid in seawater media, Deep Sea Res., Part A, 34, 1733-1743.

Erez, J. (2003), The source of ions for biomineralization in foraminifera and their implications for paleoceanographic proxies, in Biomineralization, edited by P. Dove, J. J. De Yoreo, and S. Weiner, pp. 115-149, Mineral. Soc. of Am., Washington, D. C.

Falkowski, P. G., et al. (2000), The global carbon cycle: A test of our knowledge of Earth as a system, Science, 290, $291-$ 296.

Feely, R. A., C. L. Sabine, K. Lee, W. Berelson, J. Kleypas, V. J. Fabry, and F. J. Millero (2004), Impact of anthropogenic $\mathrm{CO}_{2}$ on the $\mathrm{CaCO}_{3}$ system in the oceans, Science, 305, 362366.

Felle, H. H. (1994), The $\mathrm{H}+/ \mathrm{Cl}-$ symporter in root-hair cells of Sinapis alba (an electrophysiological study using ionselective microelectrodes), Plant Physiol., 106, 1131-1136.

Geisen, M., J. R. Young, I. Probert, A. G. Sáez, K.-H. Baumann, J. Bollmann, L. Cros, C. de Vargas, L. K. 
Medlin, and C. Sprengel (2004), Species level variation in coccolithophores, in Coccolithophores - From Molecular Processes to Global Impact, edited by H. R. Thierstein and J. R. Young, pp. 327-366, Springer, New York.

Gran, G. (1952), Determination of the equivalence point in potentiometric titrations of seawater with hydrochloric acid, Oceanol. Acta, 5, 209-218.

Guillard, R. R. L., and J. H. Ryther (1962), Studies of marine planktonic diatoms, I, Cyclotella nanna (Hustedt) and Detonula convervacea (Cleve), Can. J. Microbiol., 8, 229-239.

Hay, W. W. (2004), Carbonate fluxes and calcareous phytoplankton, in Coccolithophores - From Molecular Processes to Global Impact, edited by H. R. Thierstein and J. R. Young, pp. 509-528, Springer, New York.

Henriksen, K., S. L. S. Stipp, J. Young, and M. E. Marsh (2004), Biological control on calcite crystallization: AFM investigation of coccolith polysaccharide function, $\mathrm{Am}$. Mineral., 89, 1586-1596.

Houghton, J. T., Y. Ding, D. J. Griggs, M. Noguer, P. J. Van der Linden, X. Dai, K. Maskell, and C. A. Johnson (2001), Climate Change 2001: The Scientific Basis: Contribution of Working Group I to the Third Assessment Report of the Intergovernmental Panel of Climate Change, Cambridge Univ. Press, New York.

Indermühle, A., et al. (1999), Holocene carbon-cycle dynamics based on $\mathrm{CO}_{2}$ trapped in ice at Taylor Dome, Antarctica, Nature, 398, 121-126.

Kleijne, A. (1990), Distribution and malformation of extant calcareous nannoplankton in the Indonesian Seas, Mar. Micropaleontol., 16, 293-316.

Kleypas, J. A., R. W. Buddemeier, D. Archer, J.-P. Gattuso, C. Langdon, and B. N. Opdyke (1999), Geochemical consequences of increased atmospheric carbon dioxide on coral reefs, Science, 284, 118-120.

Lewis, E., and D. W. R. Wallace (1998), Program developed for $\mathrm{CO}_{2}$ system calculations, Carbon Dioxide Inf. and Anal. Cent., Rep. ORNL/CDIAC-105, Oak Ridge Natl. Lab., U.S. Dep. of Energy, Oak Ridge, Tenn.

Marsh, M. E. (1994), Polyanion-mediated mineralization-Assembly and reorganization of acidic polysaccharides in the Golgi system of a coccolithophorid alga during mineral deposition, Protoplasma, 177, 108-122.

Medlin, L. K., G. L. A. Barker, J. C. Green, D. E. Hayes, D. Marie, S. Wrieden, and D. Vaulot (1996), Genetic characterization of Emiliania huxleyi (Haptophyta), J. Mar. Syst., 9, 13-32.

Mehrbach, C., C. H. Culberson, J. E. Hawley, and R. M. Pytkovicz (1973), Measurement of the apparent dissociation constants of carbonic acid in seawater at atmospheric pressure, Limnol. Oceanogr., 18, 897-907.

Niebler, H.-S., H. W. Arz, B. Donner, S. Mulitza, J. Pätzold, and G. Wefer (2003), Sea surface temperatures in the equatorial and South Atlantic Ocean during the Last Glacial Maximum (23-19 ka), Paleoceanography, 18(3), 1069, doi:10.1029/2003PA000902.

Nimer, N. A., C. Brownlee, and M. J. Merrett (1994), Carbon dioxide availability, intracellular $\mathrm{pH}$ and growth rate of the coccolithophore Emiliania huxleyi, Mar. Ecol. Prog. Ser., $109,257-262$

Odijk, T. (1977), Polyelectrolytes near the rod limit, J. Polymer Sci. Polymer Phys. Ed., 15, 477-483.

Paasche, E. (2002), A review of the coccolithophorid Emiliania huxleyi (Prymnesiophyceae), with particular reference to growth, coccolith formation, and calcification-photosynthesis interactions, Phycologia, 40, 503-529.

Pearson, P. N., and M. R. Palmer (2000), Atmospheric carbon dioxide concentrations over the past 60 million years, Nature, 406, 695-699.

Perch-Nielsen, K. (1985), Cenozoic calcareous nannofossils, in Plankton Stratigraphy, edited by H. M. Bolli, J. B. Saunders, and K. Perch-Nielsen, pp. 427-555, Cambridge Univ. Press, New York.

Petit, J. R., et al. (1999), Climate and atmospheric history of the past 420,000 years from the Vostok ice core, Antarctica, Nature, 399, 429-436.

Pflaumann, U., et al. (2003), Glacial North Atlantic: Sea-surface conditions reconstructed by GLAMAP 2000, Paleoceanography, 18(3), 1065, doi:10.1029/2002PA000774.

Retallack, G. J. (2001), A 300-million-year record of atmospheric carbon dioxide from fossil plant cuticles, Nature, 411, 287-290.

Riebesell, U., I. Zondervan, B. Rost, P. D. Tortell, R. E. Zeebe, and F. M. M. Morel (2000), Reduced calcification of marine plankton in response to increased atmospheric $\mathrm{CO}_{2}$, Nature, 407, 364-367.

Sabine, C. L., et al. (2004), The oceanic sink for anthropogenic $\mathrm{CO}_{2}$, Science, 305, 367-371.

Skolnick, J., and M. Fixman (1977), Electrostatic persistence length of a wormlike polyelectrolyte, Macromolecules, 10, 944-948.

Stoll, M. H. C., K. Bakker, G. H. Nobbe, and R. R. Haese (2001), Continuous-flow analysis of dissolved inorganic carbon content in seawater, Anal. Chem., 73, 4111-4116.

Stolte, W., G. W. Kraay, A. A. M. Noordeloos, and R. Riegman (2000), Genetic and physiological variation in pigment composition of Emiliania huxleyi (Prymnesiophyceae) and the potential use of its pigment ratios as a quantitative physiological marker, J. Phycol., 96, 529-589.

Thoresen, S. S., J. R. Clayton Jr., and S. I. Ahmed (1984), The effect of short-term fluctuations in $\mathrm{pH}$ on NO-3 uptake and intracellular constituents in Skeletonema costatum (Grev.) Cleve, J. Exp. Mar. Biol. Ecol., 83, 149-157.

van Andel, T. H., J. Thiede, J. G. Sclater, and W. W. Hay (1977), Depositional history of the South Atlantic Ocean during the last 125 million years, J. Geol., 85, 651-698.

Wolf-Gladrow, D. A., U. Riebesell, S. Burkhardt, and J. Bijma (1999), Direct effects of $\mathrm{CO}_{2}$ concentration on growth and isotopic composition of marine plankton, Tellus, Ser. B, 51, $461-476$

Zondervan, I., B. Rost, and U. Riebesell (2002), Effect of $\mathrm{CO}_{2}$ concentration on the PIC/POC ratio in the coccolithophore Emiliania huxleyi grown under light-limiting conditions and different daylengths, J. Exp. Mar. Biol. Ecol., 272, $55-70$. 